\title{
Consumer Behavior: A Literature Review of the Early Research on the COVID-19 Outbreak
}

Pedro Mota Veiga * Julien Diogo **

\begin{abstract}
The outbreak of COVID-19 has substantially altered trends and the research agenda in Consumer Behavior (CB). The main objectives of this article is analyze and classify the main contributions published the early research on CB on the COVID-19 pandemic, seeking to discover the perspective and the gaps and outline future avenues of research . With this article, we performed a systematic literature review based on articles published in Web of Science (WoS). We used a bibliometric approach based on Bibliographic Coupling of Documents complemented by a thematic analysis which allows us to provide a more holistic overview of the domain under study. Based on literature review six key thematic areas were identified in CB research of early stage of the pandemic: Environmental Factors, Social Media CB and Business Strategies, Personal and Psychological Characteristics, Purchase Process, and Panic buying. The conclusions present limitations inherent to systematic literature review articles, in particular the filters used to limit the search.
\end{abstract}

Keywords: Consumer behavior, decision-making process, COVID-19, systematic literature review, bibliometric, research agenda

\footnotetext{
* School of Education, Polytechnic Institute of Viseu; University of Beira Interior \& NECE Research Unit in Business Sciences, Portugal. E-Mail: motaveiga@gmail.com

** School of Education, Polytechnic Institute of Viseu, Portugal: E-Mail: jdiogo@esev.ip.pt
} 
Received on: $2021 / 09 / 28$

Approved on: 2021/12/30

Evaluated by a double blind review system

\section{INTRODUCTION}

The outbreak of COVID-19 has substantially altered trends and the research agenda in a wide range of areas, especially in business studies. Research after the COVID-19 pandemic will be increasingly challenging and the impact of the pandemic situation on $\mathrm{CB}$ has become a new trend for the research agenda on the topic. Since the beginning of the pandemic, several articles have been published on CB during the COVID-19 pandemic . However, the scientific literature reporting on $\mathrm{CB}$ in this context remains scattered across different sources and is not in any way systematized. To help business practitioners and researchers understand the impact of the pandemic on $\mathrm{CB}$, this research it is intended to answer the following research questions (RQ):

RQ 1: What are the main topics developed in CB literature on COVID-19?

RQ 2: What are the main research gaps in CB literature and how could future avenues of research be shaped?

This paper investigates the CB during the pandemic crisis caused by COVID-19. It expands our current limited knowledge on the impact of COVID-19 on CB. This systematic literature review aims to strike at the heart of a timely academic and policy debate regarding the new trends and challenges on the $\mathrm{CB}$ in turbulent times. As the field research is ongoing and intensive, this literature review contributes to taking stock and looking forward by setting a future research agenda. To answer our objectives, we used a systematic literature review based on articles published in the WoS database and we applied the bibliometric methodology.

In terms of organization, a brief literature review is conducted in Section 2 of the article. Section 3 describes the systematic literature review methodology employed, succeeded by content analysis in Section 4. Section 5 elaborates a research agenda on CB at the time of the COVID-19 pandemic. Section 6 expounds the conclusions, the future research agenda and highlights other important considerations. 


\section{LITERATURE REVIEW}

\subsection{Consumer behavior}

There are several and diverse substantive spheres of human development (physical, perceptual, cognitive, linguistic, personality, and social), assuming that behavior can be defined as a response that is observed directly or indirectly (Esposito et al., 2017). The factors that influence CB are cultural (culture, subculture, social class), social (groups, family, roles), personal (age, occupation, economic power, lifestyle, personality), and psychological (motivation, perception, learning, beliefs, and attitudes) (Kotler et al., 2022; Schiffman \& Wisenblit, 2019). The CB is presented as the field of study that analyzes how people, groups, and organizations select, purchase, use and discard goods, services, concepts, or experiences to satisfy the needs and desires and negative reinforcement, in the first the consumer seeks comfort and satisfaction (Kotler et al., 2022; Schiffman \& Wisenblit, 2019).

Understanding the stimuli that motivate this reward and loss aversion requires analyzing and working on the motivational elements of Emotion, Attention, Cognition, and Memory (Müller-Oehring \& Schulte, 2014). People decide based on habits, personal experience, and simplified practical rules (Kahneman, 2011). They seek consistency in their beliefs and perceptions, considering that mass behaviors are born from an external influence that provides social cues (Solomon et al., 2017). Biases such as Social Proof or the Herd Effect allow validating the influence of peers on consumer behavior (Kahneman, 2011).

Having the correct information at the right time about the consumer allows the identification of competitive advantages in business relationships between brand and consumers, identifying and understanding the motivations that arise with indispensable in the current moment (Krzyk \& Kunst, 2012).

\subsection{Consumer behavior during COVID-19}

The COVID-19 period consolidated the idea of liquid modernity, and that change is the only permanent thing and uncertainty, the only certainty (Bauman, 2001).

It had already been experienced during and post the Recession between 2008 and 2010, a period during which consumer behaviors and attitudes changed (Nakano, 2012); spending was reduced overall, lower-value brands were purchased; concern about carbon footprint increased, as did environmental awareness; it was feared that society was being shallow 
(Solomon et al., 2017).

In 2020, the COVID-19 crisis changed routines at an unprecedented rate, and some of those changes will last beyond the pandemic (Tiago \& Veiga, 2021). Anxiety was driven by COVID-19 and promoted the generalization of "Panic buying" behavior (Chua, Yuen, Wang, \& Wong, 2021). When faced with an unmanageable situation, people try to resolve inadequacies and distortions by understanding their own abilities and limitations (Chua et al., 2021). Yuen, Wang, Ma, \& Li (2020) indicate that the consumer's desire to acquire control is primarily responsible for purchasing the product. Panic buying has re-emerged as a 'new' normal behavior and has become a coping mechanism for confronting real and perceived dangers associated with COVID-19 (Billore \& Anisimova, 2021). As panic continues to grow, consumer reasoning is often overtaken by feelings of anxiety rather than being consolidated with reasonable cognitive conclusions. According to data from Nielsen (2020), the population of each country reacted and promoted panic buying after two weeks of the virus' knowledge in the country. There were several categories that became a priority: medical goods, alcohol for hygiene, antibacterial wet wipes, first aid kits, antiseptics, cold remedies and cough medicines.

\section{METHODOLOGY}

In this paper, we propose a bibliometric approach based on Bibliographic Coupling of Documents complemented by a thematic analysis which allows us to provide a more holistic overview of the domain under study.

Bibliometric analysis is a methodology used on a global scale to assess the performance of the research conducted (Mutschke, Mayr, Schaer, \& Sure, 2011), comprising the application of quantitative and statistical analysis to publications such as articles and their citations, as it provides data on all the activities of a scientific domain. The summaries of these data offer a broad perspective on research activities and impacts, especially of researchers, journals, countries, and universities (Hawkins, 1977; Osareh, 1996; Thomsom Reuters, 2008).

A three-step process was adopted to implement the bibliometric methodology: 1) research and data collection, 2) definition of inclusion and exclusion criteria, 3) data analysis. Fig. 1 presents a summary of the methodology followed. 
Figure 1. Summary of methodology

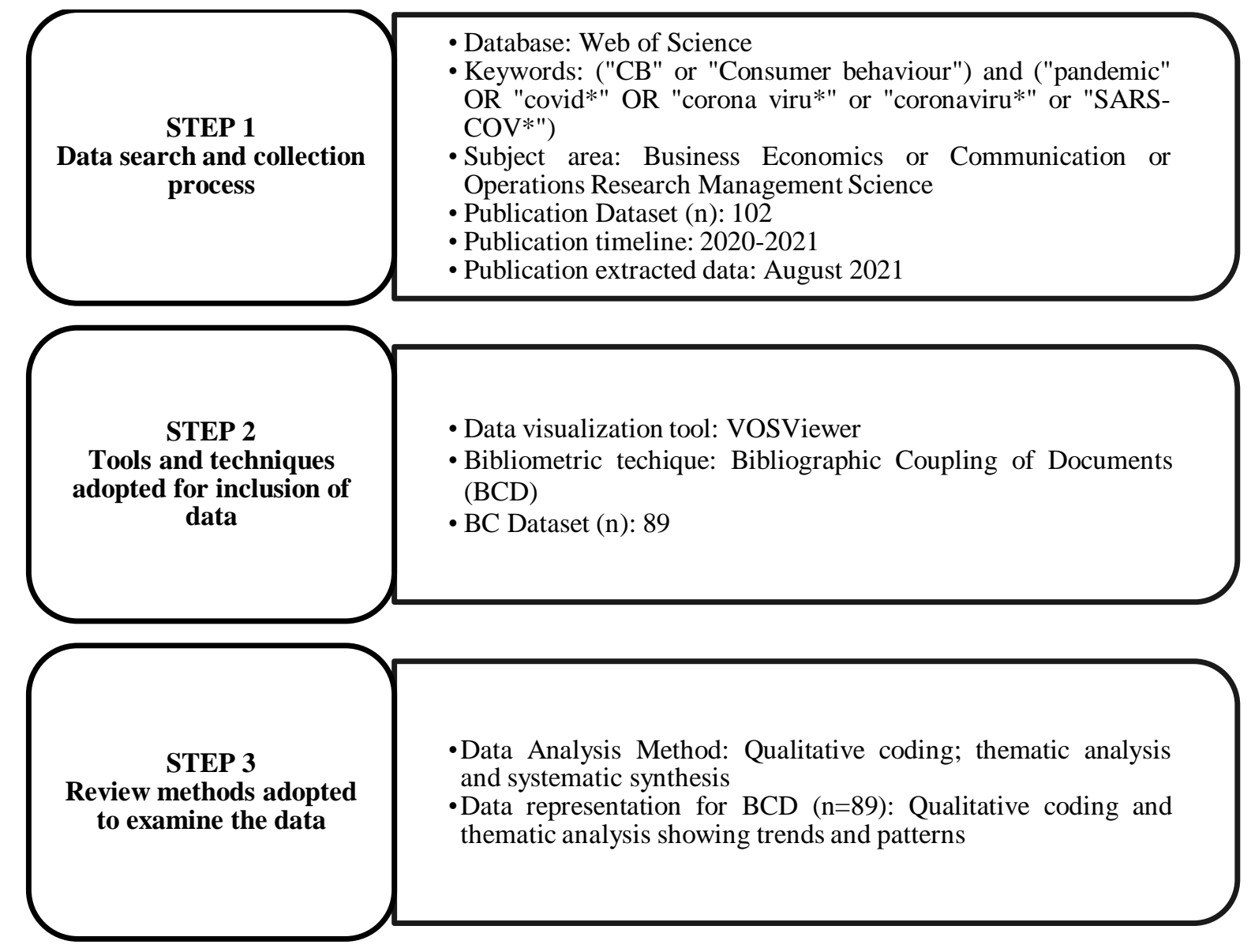

\subsection{Data search and collection}

For the search, we used the online database WoS, which contains tens of thousands of scholarly publications and bibliographic information on authors, affiliations, and citations. We used WoS database because it is recognized worldwide and highly sought after by renowned researchers and editors, due to its wide and qualified database (Almeida et al., 2021). The search was conducted in August 2020 based on articles published or accepted for publication from 2020 to the time of the search. The search was performed using the following expressions:

(Topic) "CB" or "Consumer behaviour and (Topic) "pandemic" OR "covid*" OR "corona viru*" or "coronaviru*" or "SARS-COV*" The unit of analysis of this study is the articles; 
the variables collected correspond to authors and affiliation, publication journals, number of citations and cited references. Table 1 presents a summary of the publications included in the study.

Table 1. Summary of the articles included resulting from the search

\begin{tabular}{lc}
\hline Description & Results \\
\hline Documents & 102 \\
Sources (Journals, Books, etc.) & 67 \\
Keywords Plus (ID) & 277 \\
Author's Keywords (DE) & 367 \\
Period & $2020-2021$ \\
Average citations per documents & 8,5 \\
Authors & 278 \\
Author Appearances & 299 \\
Authors of single-authored documents & 20 \\
Authors of multi-authored documents & 258 \\
Single-authored documents & 20 \\
Documents by Author & 0,367 \\
Authors per Document & 2,93 \\
\hline
\end{tabular}

\subsection{Definition of inclusion and exclusion criteria}

The mapping software VOS Viewer version 1.6.16 (van Eck \& Waltman, 2009, 2010) was employed to define the inclusion and exclusion criteria, to refine the sample of articles. The $\mathrm{BCD}$ relational technique was also used to understand the relationships between authors and research streams.

BCD allows for the study of emerging trends in a field while focusing on current trends. Bibliographic coupling links two articles that cite the same articles. The more papers they cite together, the more likely these two publications cover the same research topic. First, as the bibliometric coupling includes recent publications that have not yet been cited, we decided to select a threshold of at least one common reference, reducing our sample to 89 articles.

\subsection{Thematic analysis}

To understand CB in Pandemic COVID-19 in greater depth, we conducted qualitative coding and thematic analysis using our BCD sample $(n=89)$. The analytic coding involved 
the creation of categories, thus allowing for the analysis of existing areas of focus and the emergence of new themes. For the thematic analysis, we used the approach defined by Schiffman \& Wisenbli (2019) in consumer decision-making process includes three components: the input, process, and output stages of decision-making. The input stage of consumer decision-making includes two influencing factors: firms' marketing efforts and environmental influences. The process stage focuses on how consumers make decisions. Psychological factors influence the consumer's recognition of a need, search for information, and evaluation of alternatives. The experience gained through the evaluation of alternatives, in turn, affects the consumer's existing psychological attributes. The exit stage consists of two post-decision activities: purchase behavior and post-purchase evaluation.

\section{RESULTS}

\subsection{Summary of articles}

The first analysis of our sample of 102 articles reveals that 37 articles were published in 2020 and the remaining 65 in 2021. (32 articles), iii) quantitative (28 articles) and iv) mixed methods (7 articles).

In terms of citations, publications had an average of 5.5 citations for a total of 867 citations, 48 publications (47.1\%) had no citations, and 31 publications $(30.4 \%)$ had been cited between one and five times. Table 2 presents the five publications with the highest number of citations resulting from the research.

Table 2. Top publications in the CB domain during COVID-19 pandemic

\begin{tabular}{lc}
\hline Document & \# Citations \\
\hline Donthu \& Gustafsson(2020) & 152 \\
Sheth(2020) & 149 \\
Laato, Islam, Farooq, \& Dhir(2020) & 76 \\
Pantano, Pizzi, Scarpi, \& Dennis(2020) & 76 \\
Kirk \& Rifkin(2020) & 71 \\
\hline
\end{tabular}

Regarding the sources, the publications resulting from the search were published in 67 different sources. Table 3 presents the journals with the highest number of citations in the publications published on CB during the COVID-19 pandemic. The sources with the 
highest number of publications were the journals Journal of Retailing and Consumer Services (7 articles), Journal of Business Research (5 articles), International Journal of Consumer Studies (5 articles), Journal of Asian Finance Economics and Business (4 articles) and Caderno Profissional de Marketing UNIMEP (4 articles). The sources with the highest impact in terms of citations were Journal of Business Research (449 citations), Journal of Retailing and Consumer Services (127 citations), International Journal of Consumer Studies (39 citations), and Journal of Risk and Financial Management (38 citations).

Table 3. Main sources in the CB domain during pandemic COVID-19

\begin{tabular}{lcc}
\hline Source Title & \# Articles & \# Citations \\
\hline Journal of Retailing and Consumer Services & 7 & 127 \\
Journal of Business Research & 5 & 449 \\
International Journal of Consumer Studies & 5 & 39 \\
Journal of Asian Finance Economics and Business & 4 & 1 \\
UNIMEP Marketing Professional Notebook & 4 & 0 \\
Service Industries Journal & 3 & 24 \\
Cogent Business \& Management & 3 & 8 \\
Journal of Risk and Financial Management & 2 & 38 \\
Journal of International Consumer Marketing & 2 & 27 \\
Tourism Management & 2 & 14 \\
Journal of Consumer Behaviour & 2 & 8 \\
Management \& Marketing-Challenges for the Knowledge Society & 2 & 8 \\
International Journal of Innovation Science & 2 & 4 \\
Brookings Papers on Economic Activity & 2 & 3 \\
Journal of Theoretical and Applied Electronic Commerce Research & 2 & 2 \\
Brazilian Journal of Marketing & 2 & 2 \\
International Journal of Emerging Markets & 2 & 0 \\
The Journal of Indian Management \& Strategy & 2 & 0 \\
\hline
\end{tabular}

The top countries with research expertise in CB during the COVID-19 pandemic are shown in Table 4. The United States (48 authors and 26 articles), United Kingdom (17 authors and 9 articles) and India (13 authors and 10 articles) are the countries with the largest number of publications and authors. 
Table 4. Countries with the most authors and publications in the CB domain during COVID-19 pandemic

\begin{tabular}{lc|lc}
\hline Country & \# Authors & Country & \# Articles \\
\hline USA & 48 & USA & 26 \\
UK & 17 & INDIA & 10 \\
BRAZIL & 15 & UK & 9 \\
INDONESIA & 15 & AUSTRALIA & 7 \\
AUSTRALIA & 13 & ITALY & 6 \\
INDIA & 13 & CHINA & 6 \\
CHINA & 11 & BRAZIL & 5 \\
FRANCE & 8 & FRANCE & 5 \\
& & INDONESIA & 5 \\
& & SPAIN & 5 \\
& & TURKEY & 5 \\
\cline { 3 - 4 } & & &
\end{tabular}

\subsection{Towards an organizing framework of CB in Pandemic times}

The initial sample of 102 publications contained 5232 cited references. However, the sample was reduced to 89 publications that had common references. Based on the bibliographic coupling matrix, the matrix of common references among the 89 publications was determined in order to elaborate the network of connections between the publications and the grouping into clusters. Figure 2 shows the network of articles and the respective clusters obtained through the methodology defined by van Eck \& Waltman $(2009,2010)$, using the data from the common references matrix. For a better analysis of the clusters, the articles that compose them are presented in Table 5. For the description of each of the six clusters, only some of the articles that compose them were discriminated. 


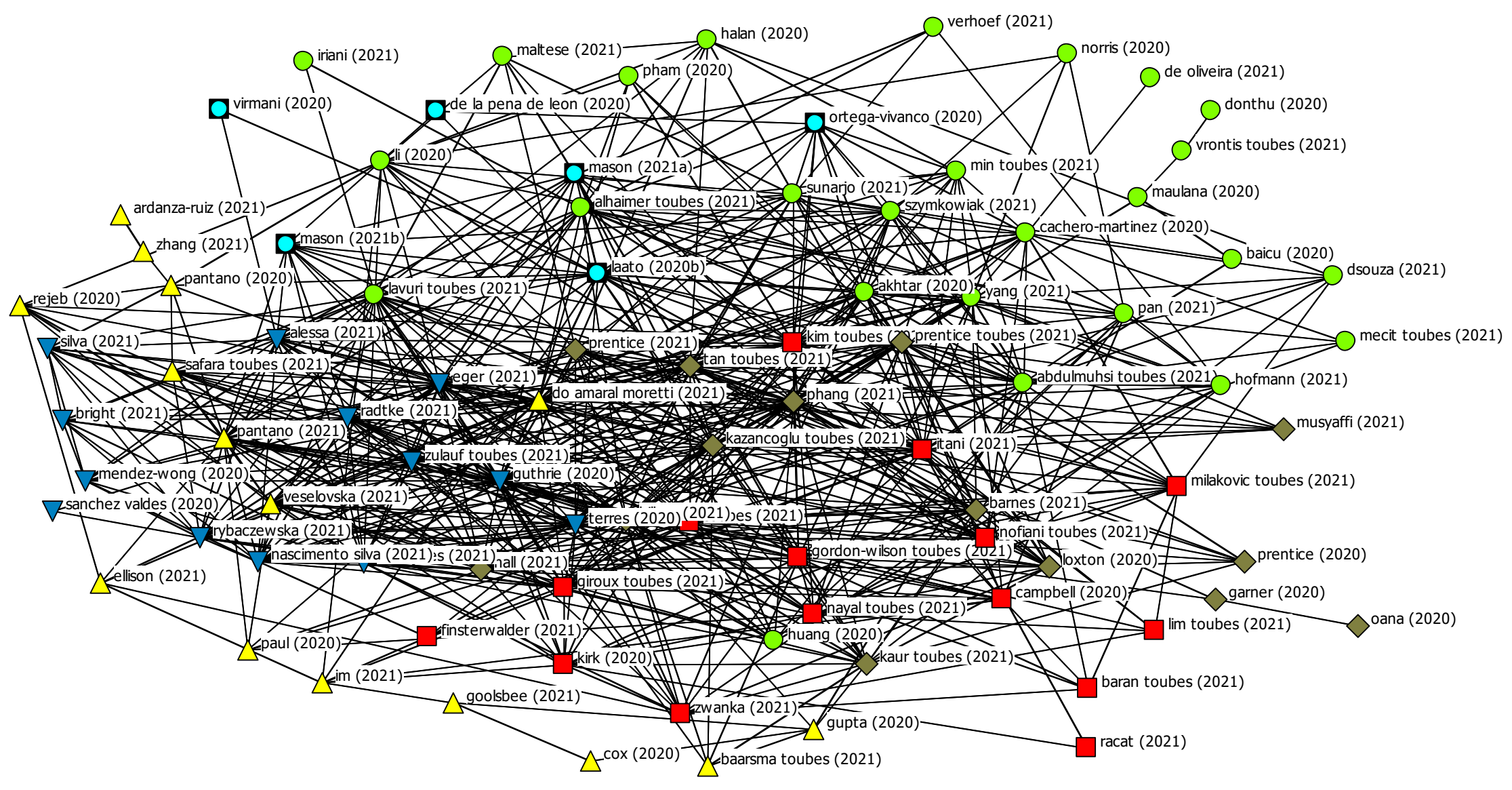

Figure 2. Bibliographic coupling network of the 90 publications and respective clusters 
Table 5. Clusters of bibliographic coupling of documents

\begin{tabular}{|c|c|}
\hline Clt & Articles \\
\hline $\begin{array}{l}\text { Personal and } \\
\text { psychological } \\
\text { characteristics } \\
\text { (26 articles) }\end{array}$ & $\begin{array}{l}\text { Abdulmuhsin, Degirmenci, Efendioglu, \& Durmaz, 2021; Akhtar, Akhtar, Usman, } \\
\text { Ali, \& Siddiqi, 2020; Alhaimer, 2021; Baicu, Gardan, Gardan, \& Epuran, 2020; } \\
\text { Cachero-Martinez, 2020; de Oliveira et al, 2021; Donthu \& Gustafsson, 2020; } \\
\text { Dsouza \& Sharma, 2021; Halan, 2020; Hofmann, Stokburger-Sauer, Wanisch, \& } \\
\text { Hebborn, 2021; Huang \& Liu, 2020; Iriani, Nuswantara, Kartika, \& } \\
\text { Purwohandoko, 2021; Lavuri, 2021; Li, Hallsworth, \& Coca-Stefaniak, 2020; } \\
\text { Maltese, Le Pira, Marcucci, Gatta, \& Evangelinos, 2021; Maulana, 2020; Mecit, } \\
\text { Shrum, \& Lowrey, 2021; Min, Yang, \& Kim, 2021; Norris, de Calvo, \& Mather, } \\
\text { 2020; Pan, Shu, Kitterlin-Lynch, \& Beckman, 2021; Pham, Do Thi, \& Ha Le, } \\
\text { 2020; Sunarjo, Nurhayati, \& Muhardono, 2021; Szymkowiak, Gaczek, Jeganathan, } \\
\text { \& Kulawik, 2021; Verhoef, 2021; Vrontis \& Basile, 2021; Yang, Kim, Min, \& } \\
\text { Hernandez-Calderon, 2021). }\end{array}$ \\
\hline $\begin{array}{l}\text { Environmental } \\
\text { factors } \\
(15 \text { articles })\end{array}$ & $\begin{array}{l}\text { (Baran, 2021; Campbell, Inman, Kirmani, \& Price, 2020; Finsterwalder, Kabadayi, } \\
\text { Fisk, \& Boenigk, 2021; Giroux et al, 2021; Gordon-Wilson, 2021; Itani \& } \\
\text { Hollebeek, 2021; Kim, Yang, Min, \& White, 2021; Kirk \& Rifkin, 2020; Lim, } \\
\text { 2021; Milakovic, 2021; Nayal, Pandey, \& Paul, 2021; Nofiani, Indarti, Lukito- } \\
\text { Budi, \& Manik, 2021; Racat, Capelli, \& Lichy, 2021; Toubes, Araujo Vila, \& Fraiz } \\
\text { Brea, 2021; Zwanka \& Buff, 2021). }\end{array}$ \\
\hline $\begin{array}{l}\text { Business and } \\
\text { Marketing } \\
\text { strategies } \\
\text { (15 articles) }\end{array}$ & $\begin{array}{l}\text { (Ardanza-Ruiz \& Lavin, 2021; Baarsma \& Groenewegen, 2021; Cox et al, 2020; } \\
\text { do Amaral Moretti, da Silva Gabriel, do Prado, \& Alcantara Fagundes, 2021; } \\
\text { Ellison, McFadden, Rickard, \& Wilson, 2021; Goolsbee \& Syverson, 2021; Gupta, } \\
\text { Simon, \& Wing, 2020; Im, Kim, \& Choeh, 2021; Pantano et al, 2020; Pantano, } \\
\text { Priporas, Devereux, \& Pizzi, 2021; Paul, Menzies, Zutshi, \& Cai, 2020; Rejeb, } \\
\text { Rejeb, \& Keogh, 2020; Safara, 2021; Veselovska, Zavadsky, \& Bartkova, 2021; } \\
\text { Zhang, Liu, \& Yao, 2021). }\end{array}$ \\
\hline $\begin{array}{l}\text { Panic buying } \\
\text { (14 articles) }\end{array}$ & $\begin{array}{l}\text { (Barnes, Diaz, \& Arnaboldi, 2021; Billore \& Anisimova, 2021; Garner, Safir, \& } \\
\text { Schild, 2020; Hall, Fieger, Prayag, \& Dyason, 2021; Kaur \& Malik, 2021; } \\
\text { Kazancoglu \& Demir, 2021; Loxton et al, 2020; Musyaffi, Sari, \& Respati, 2021; } \\
\text { Oana, 2020; Pham et al., 2020; Prentice, Chen, \& Stantic, 2020; Prentice, Nguyen, } \\
\text { et al., 2021; Prentice, Quach, \& Thaichon, 2021; Tan, Sia, \& Tang, 2021). }\end{array}$ \\
\hline $\begin{array}{l}\text { ase Process } \\
\text { ticles) }\end{array}$ & $\begin{array}{l}\text { (Alessa, Alotaibie, Elmoez, \& Alhamad, 2021; Bright \& Schau, 2021; Eger, } \\
\text { Komarkova, Egerova, \& Micik, 2021; Guthrie, Fosso-Wamba, \& Arnaud, 2020; } \\
\text { Liu, Xia, \& Lang, 2021; Mendez-Wong, Ana Aguilar-Garces, Alicia Villarreal- } \\
\text { Cavazos, \& Alcantara Hernandez, 2020; Radtke, Brock, Ostermann, \& De } \\
\text { Almeida, 2021; Rybaczewska, Sulkowski, \& Bilan, 2021; Sanchez-Valdes \& } \\
\text { Nava-Rogel, 2020; E. S. Silva \& Bonetti, 2021; L. E. N. Silva, Neto, Grangeiro, \& } \\
\text { de Nadae, 2021; Terres et al., 2020; Zulauf \& Wagner, 2021) }\end{array}$ \\
\hline $\begin{array}{l}\text { Social media } \\
\text { behaviors } \\
\text { ( } 6 \text { articles) }\end{array}$ & $\begin{array}{l}\text { (de la Pena de Leon, Saucedo Soto, Amezcua Nunez, \& Balleza, 2020; Laato et al., } \\
\text { 2020; Mason, Brown, Mason, \& Narcum, 2021; Mason, Narcum, \& Mason, 2021; } \\
\text { Ortega-Vivanco, 2020; Virmani \& Kaur, 2020). }\end{array}$ \\
\hline
\end{tabular}

\section{Cluster 1: Personal and psychological characteristics}

Consumers' personal and psychological characteristics have been extensively studied in the 
early stages of COVID-19, characterized by confinement and social distancing. Most of the studies included in the research conducted fall within this cluster. Consumers' personal and psychological characteristics determine how they respond to stimuli.

Maltese et al.(2021) investigated consumers' preference for grocery stores or e-grocers specifically, according to several characteristics related to socio-economic aspects (age, gender, employment status, family size, income, region where they live), mobility patterns (dedicated vs. non-dedicated trips; modal choice: driving car or walking), shopping habits (volume of purchases; frequency of purchases; cost of purchases), and familiarity with egrocers (experience, knowledge, intention/propensity). Lavuri(2021), based on the stimulus - organism - response (S - O - R) paradigm and dual-factor theory, examined the effect of intrinsic factors (Perceived Utility Value; Perceived Hedonic Value, Materialism, Interest in Fashion and Pleasure) on impulsive online shopping by Indians, as well as with the dual mediating role of trust and attitude in this effect. Thus, based on the S - O - R approach, Lavuri(2021) explores the relationship between stimulus factors (intrinsic factors), organism factors (mediating factors), and response factors (impulsive online shopping). Cachero-Martinez (2020) analyzed the association between attitude, satisfaction, trust, purchase intention, and word-of-mouth (WOM) promotion towards organic products in a sample of Spanish consumers. Cachero-Martinez(2020) concluded that trust is influenced by satisfaction and attitude. Satisfaction is the variable that most influences purchase intentions and WOM intentions. A moderating effect of environmental concern is observed in the proposed relationships. Baicu et al. (2020) developed a conceptual model on the acceptance of mobile Internet banking services by Romanian consumers, highlighting that the perception of the effect of the COVID-19 pandemic on consumers' lifestyle directly and positively influences the variable related to attitude towards Internet and mobile banking services, mediated by other variables such as safety of Internet and mobile banking use and trust in banks. Based on the Theory of Planned Behavior, Sunarjo et al.(2021) studied the impact of technology user characteristics, knowledge, and utility value assigned on the use of mobile payments among Indonesian consumers. Alhaimer(2021) assessed the effect of various perceived risk factors (financial risk, product risk, convenience risk, non-delivery risk, risk susceptibility, risk severity, and risk of formal penalties) on consumers' online shopping behavior during the COVID-19 pandemic in Kuwait. 
The main ideas advocated by the various authors in Personal and psychological are the impact of age (generation), gender, employment status, family size, income, place of residence, mobility patterns, shopping habits, and lifestyles on CB.

\section{Cluster 2: Environmental factors}

Environmental factors correspond to a set of agents with which the consumer has indirect interactions, and technological, political-legal, economic, and socio-cultural environments arising from the pandemic COVID-19 can be considered key forces.

Campbell et al. (2020) developed a conceptual framework on what threats affect consumer responses and lead to market adaptations. These authors propose that contexts such as pandemics can lead to disruptions that negatively affect consumers' ontological security and are associated with various consumer responses, ranging from short-term affective and psychological, long-term psychological, and behavioral. Zwanka \& Buff (2021) also developed a conceptual framework on $\mathrm{CB}$ changes resulting from the pandemic. This conceptual framework addresses production within borders as supply chain security, online ordering, return to experience and hedonism, work at home and worker status, political discontent, online transactions not previously available, virtual reality replacing travel, cooking at home, increased focus on environmental stewardship, social supports, and longterm psychographic changes in beliefs.

COVID-19 and the confluence of available technology have induced consumers to adopt technologies massively and rapidly and increase their consumption of highly digital business formats, impacting marketers and customers in the coming years. Racat et al. (2021) explored the use of haptic rendering stimulation for pre-purchase decision making, namely identifying how to touch on an interface can influence product evaluation and purchase intention. Racat et al. (2021) concluded that touch on the interface is important for inferring product information or pleasure in interacting with the product, confirming the relationship between mental knowledge and representation, sensory, bodily motor actions, and online shopping contexts.

The global humanitarian crisis COVID-19 has proven to be a crisis that has affected tourism like no other (Lim, 2021). Lim (2021) used crowding theory as a theoretical lens of CB and COVID-19 as a context to represent a global humanitarian crisis to assess the cases of under crowding (undertourism) and overcrowding (overtourism) in tourism as a result of 
COVID-19. The crowding theory was established as a CB theory used to guide crowd density in tourism destinations. Lim (2021) developed a new theory called the Agency and reactance theory of crowding based on these assumptions. Itani \& Hollebeek (2021) investigated the role of perceived threat assessment of COVID-19 by visitors to tourist attraction sites, specifically the impact of perceived severity of the pandemic health threat, perceived susceptibility to contracting the virus, and social distancing behavior on consumers' intention to purchase a virtual reality-based website tour as an alternative to visiting in person during and after the pandemic. Toubes et al. (2021) analyzed the main changes in promotion and marketing in the tourism sector in Spain after the pandemic, revealing that online information sources have gained weight over consultations with friends and relatives. A major advance in digitalization is expected, where physical travel agencies will be replaced by online platforms, except for specialized and advisory services. Toubes et al. (2021) refer that technologies such as virtual reality or artificial intelligence will play an increasingly predominant role in the tourism industry.

In the Environmental factors, the main ideas researched are the perceptions of security, production within borders as supply chain security, online ordering, work at home and worker status, and long-term psychographic changes in beliefs. Restrictive measures, technological, political-legal, economic, and socio-cultural environments are also environmental factors researched. Some other articles in this set researched the increasingly prominent role in the tourism industry played by technologies such as virtual or augmented reality or artificial intelligence. COVID-19 and the confluence of available technology have induced consumers to adopt technologies massively and rapidly and increase their consumption of highly digital business formats, impacting merchants and customers in the coming years.

\section{Cluster 3: Business and marketing strategies}

With COVID-19, companies had to change many of their strategies to mitigate several risks and the increment of the benefits perceived by the consumer. Ardanza-Ruiz \& Lavin (2021) investigated how two large retail companies varied their communication strategies and content, including neuromarketing in social networks, given the situation in Spain with COVID-19. Ardanza-Ruiz \& Lavin (2021) concluded that a change occurred in the advertising content seeking to pass a message of support and encouragement to customers, 
positive messages, and messages that "humanize" them as companies and that this change was due to studies conducted with approaches supported in neuromarketing. Pantano et al. (2021) identified the strategies that companies can adopt to meet the expectations of new consumers shaped by the emergency period, concluding companies should continue to advertise and promote their products during future periods of national or international emergency following consumer expectations and focus on creating a quality experience for consumers. Pantano et al. (2020) address the communication of shared beliefs by retail companies and that there is a common goal that should be perceived, putting people before profit. Pantano et al. (2020) suggest that retailers focus on key areas to address the unprecedented demand and pressure caused by the emergence of COVID-19. The key areas identified are rethinking more agile retailing, notably developing dynamic capabilities; recognising the key role played in society and its human resources as essential workers; putting consumers at the centre, ensuring consumers' safety and health and valuing their sense of well-being; and digital communication, particularly customer relationship management systems and enhancing secure interactions with customers. Paul et al. (2020) examined the new business paradigms, in China and India, in the context of COVID 19, addressing topics such as innovation, exports, foreign direct investment, technology allied to CB. In the Slovak context, Veselovska et al. (2021) analyzed the changing needs in CB, indicating that companies need to learn to understand and accommodate these newly developed needs, instill a sense of security in their customers, as well as quickly investigate the new needs of their customers and seize this opportunity to evolve.

In general, the articles about Business and Marketing strategies showed that main strategies of the companies during the period were innovation, exports, foreign direct investment, technology allied to the CB in daily evolution. Alteration of communication strategies and advertising content seeking to convey a message of support and encouragement to customers, positive messages, and messages that "humanize" them as companies and the importance of consumer centricity are also explored in the papers published in this cluster. Some articles address companies' need for learning and understanding to accommodate the newly developed needs of consumers and take this opportunity to evolve. Topics such as ensuring the safety and health of consumers and improving their sense of well-being were also researched. 


\section{Cluster 4: Panic buying}

Despite the great interest in consumers' personal and psychological processes, purchasing decision-making has attracted less attention. One area of $\mathrm{CB}$ that caught retailers and supply chains unprepared during the early stages of the COVID-19 pandemic was the abrupt increase in purchasing certain utilitarian goods, the impulsive and panic buying common to disruptive events (Barnes et al., 2021). Barnes et al. (2021), based on compensatory control theory, analyzed panic buying during the pandemic, concluding that anxiety generated a lack of perceived control, which led to the purchase, and that consumers are expected to behave irrationally and purchase larger volumes of staple foods than strictly necessary as they seek to regain control by welcoming a sense of problemsolving through the purchase of utilitarian products. Billore \& Anisimova (2021) conducted a systematic review of the literature on panic buying and systematized the existing studies on panic buying as this behavior was extremely pronounced during COVID-19. In another literature review, Loxton et al.(2020) analyzed the various CB theories and behavioral models presented in some historical panic periods (the SARS outbreak, the Christchurch earthquake, and Hurricane Irma) to understand how different events caused a change in CB. Loxton et al.(2020) assessed spending patterns according to time, volume, and range of purchases that may indicate panic buying, herd mentality, and consumer shopping intentions (Maslow's needs), and how these same behaviours were reproduced during the global pandemic period, Hall et al. (2021) examined consumer buying behaviour, retail spending, and transactional data for different retail sectors in New Zealand. Once COVID19-related panic shopping commenced, Hall et al.(2021) found that overall spending increased sharply in anticipation of confinements, with the magnitude of the panic shopping event far exceeding historical seasonal patterns of consumer spending such as Christmas, Easter, and Black Friday. These authors highlight the importance of comparing panic buying with other events regarding purchase motivations and consider that so-called panic buying can contribute to greater individual and family resilience. Kaur \& Malik(2021) explored the factors that explain the reasons for consumers' panic buying in the emergence of COVID-19 through the experience of retail operators who faced challenges in supplying and managing their stock, theorizing that possible supply disruption, emotional contagion, inability to tolerate stress, and some demographic characteristics have an impact on panic 
buying. Prentice et al.(2020) examined and confirmed the connection between the time between government measures and panic buying in Australia. Prentice, Nguyen, et al.(2021) explored the impact on panic purchases of external factors such as government intervention and support to combat and manage the pandemic, business intervention and support to prevent hoarding or lack of stokes, and the influence of different categories of social groups that may influence panic purchases and how they are related. Based on data from five countries (Australia, India, China, Vietnam, and Indonesia), Prentice, Nguyen, et al.(2021) showed that government and business interventions and support influenced the increase of panic buying, while social groups did not reveal this effect. Prentice, Quach, et al.(2021) used the scarcity principle in crowd psychology and contagion theory to explain panic buying. Prentice, Quach, et al. (2021) used government measures, media, and peer influence as antecedents. The fear of missing out and consequences are supported in a sense of security and guilt. Results for a sample of consumers from Australia and the United States who engaged in panic shopping showed that the proposed antecedents (except the fear of missing out) were associated with panic buying, which impacted these consumers' psychological outcomes.

The researched linked with this clusters showed that panic can contribute to greater individual and family resilience and the anxiety is offset by the consumer's desire to acquire control, becoming the main responsible for purchasing the product.

\section{Cluster 5: Purchase process}

Guthrie et al.(2020) analyzed how online drug purchasing behaviors evolved before, during, and after confinement in France due to COVID-19. Guthrie et al.(2020) extended the React-Cope-Adapt (RCA) model to analyze the acquisition process, concluding that online purchases of essential para pharmaceuticals increased during the adaptation phase and that disruptive events, such as a pandemic, may produce online purchasing behaviors as part of problem-focused and emotion-focused coping strategies. Liu et al.(2021) present a framework of the evolution of clothing consumption to understand how consumers changed in consumption amid the global COVID-19 pandemic. This exploratory study is intended during the pandemic crisis. Liu et al.(2021) took an approach that aggregates the perspectives of changes in life status and stress coping, concluding that change in consumption is the key coping mechanism for dealing with stress. Eger et al.(2021) 
examined the impact of the COVID-19 pandemic on changes in consumer purchasing habits at the onset of the second wave of the COVID-19 pandemic in the Czech Republic by investigating changes in the purchase of selected products in physical and online stores in relation to COVID-19 pandemic-related fears. Terres et al. (2020) proposed that prosocial consumption could help reduce the negative emotional effects caused by social withdrawal and promote consumer well-being during the COVID-19 crisis and increase brands' perceived value. Silva \& Bonetti (2021) analyzed fashion products consumers' attitudes towards the propensity to interact with digital humans, concluding that digital humans may change the way companies interact with consumers in terms of sales channels and communication channels.

The main topics researched in the Purchase Process address the need for convenience when purchasing products, reducing expenses, purchasing cheaper products, increasing the concern with the carbon footprint, as well as environmental awareness. Some articles researched the use by brands of messages to support and encourage customers, positive messages and messages that humanize them. The focus has become increasingly on experience by brands.

\section{Cluster 6: Social media CB}

During COVID-19, consumers use information as a valuable factor in decision-making. Laato et al.(2020) proposed a conceptual model linking exposure to online information sources to two behavioral responses: unusual shopping and self-isolation. Laato et al.(2020) conclude that exposure to online information sources led to increased information overload and cyberchondria and that perceived situation severity and cyberchondria had significant impacts on people's intention to make unusual purchases and isolate themselves. Social media is a common source of information, and in this regard, Mason, Brown, et al.(2021) examined whether COVID-19 impacted the social media consumer behaviors of Indian consumers, concluding that it occurred that an increase in the use of social media consumer behaviors, increasing their reliance on social media for their consumer decision-making behaviors. In a similar approach, Mason, Narcum, et al.(2021) explore the role that social media plays in the consumer decision-making process, and the results reveal that social media is appropriate for building consumers' brand and product knowledge as consumers are increasingly using social media to identify product needs, to compare product 
alternatives, assess product risks and make purchases. Ortega-Vivanco (2020) analyzed the factors of $\mathrm{CB}$, indicating that online communication and social networks have been useful to connect both with the closest environment as in the professional environment and consequently has influenced the buying behavior of consumers in Ecuador.

The researched in this cluster shows that Social media emerge as fundamental to maintain the feeling of proximity to peers and security in access to knowledge. Social media have promoted increased information overload and cybercrime, registering an evolution of the perceived severity of the situation and cybercrime. Some articles indicated that online shopping for essential products increased during the adjustment phase and others researched the importance of touching the interface of the technological device to infer information about the products.

Figure 3 presents the conceptual model that aggregates these six thematic areas identified for the CB, and in Table 6, we summarize the main ideas advocated by the various authors in each thematic area.0.

Figure 3. Conceptual model

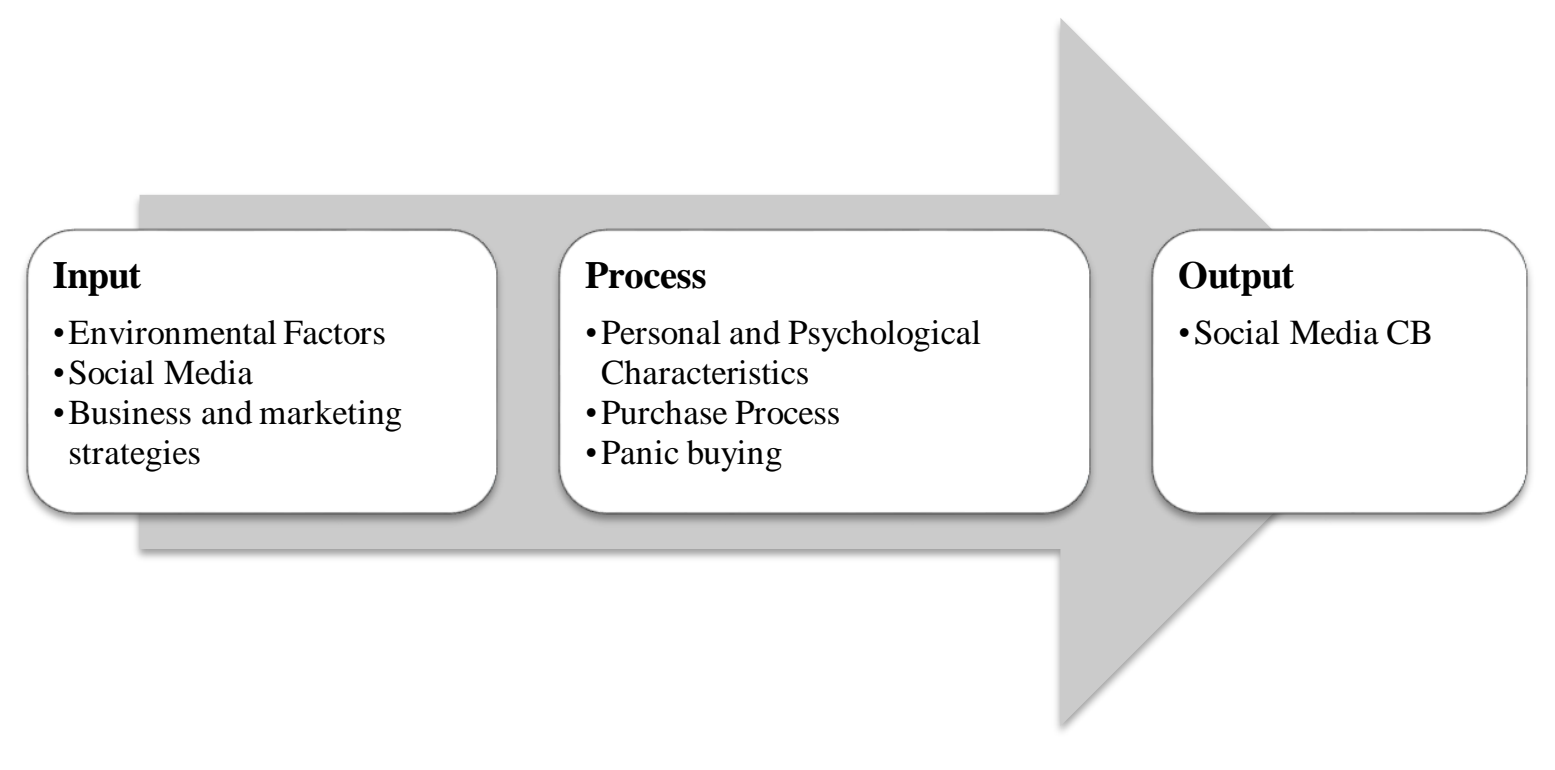


Table 6. Review insights of Prevailing Approaches

\begin{tabular}{|c|c|}
\hline Prevailing Approaches & Review insights \\
\hline $\begin{array}{l}\text { Cluster 1: Personal and } \\
\text { psychological } \\
\text { characteristics }\end{array}$ & $\begin{array}{l}\text { - Impact of age (generation), gender, employment status, family size, } \\
\text { income, place of residence, mobility patterns, shopping habits, and } \\
\text { lifestyles on CB. }\end{array}$ \\
\hline $\begin{array}{l}\text { Cluster 2: } \\
\text { Environmental factors }\end{array}$ & $\begin{array}{l}\text { - Technologies such as virtual reality or artificial intelligence will play an } \\
\text { increasingly prominent role in the tourism industry. } \\
\text { - Restrictive measures, technological, political-legal, economic, and } \\
\text { socio-cultural environments are arising from the pandemic COVID-19. } \\
\text { - Perceptions of security, production within borders as supply chain } \\
\text { security, online ordering, work at home and worker status, and long- } \\
\text { term psychographic changes in beliefs. } \\
\text { - COVID-19 and the confluence of available technology have induced } \\
\text { consumers to adopt technologies massively and rapidly and increase } \\
\text { their consumption of highly digital business formats, impacting } \\
\text { merchants and customers in the coming years. }\end{array}$ \\
\hline $\begin{array}{l}\text { Cluster 3: Business and } \\
\text { marketing strategies }\end{array}$ & $\begin{array}{l}\text { - Clear bets of the companies during the period were innovation, exports, } \\
\text { foreign direct investment, technology allied to the CB in daily evolution. } \\
\text { - Brands have promoted the importance of consumer centricity. } \\
\text { - Alteration of communication strategies and advertising content seeking } \\
\text { to convey a message of support and encouragement to customers, } \\
\text { positive messages, and messages that "humanize" them as companies } \\
\text { - Ensuring the safety and health of consumers and enhancing their sense } \\
\text { of well-being } \\
\text { - Companies have had to learn to understand and accommodate newly } \\
\text { developed needs and take this opportunity to evolve. }\end{array}$ \\
\hline Cluster 4: Panic buying & $\begin{array}{l}\text { - Panic can contribute to greater individual and family resilience. } \\
\text { - Anxiety is offset by the consumer's desire to acquire control, becoming } \\
\text { the main responsible for purchasing the product. }\end{array}$ \\
\hline $\begin{array}{l}\text { Cluster 5: Purchase } \\
\text { Process }\end{array}$ & $\begin{array}{l}\text { - Consumers crave convenience. } \\
\text { - Spending was reduced overall, lower-value brands were purchased; } \\
\text { concern about carbon footprint increased, as did environmental } \\
\text { awareness. } \\
\text { - The focus has become increasingly on experience on the part of brands. } \\
\text { - Brands promoted messages of support and encouragement to customers, } \\
\text { positive messages, and messages that "humanize" them. } \\
\text { - Humanization changed brand advertising. }\end{array}$ \\
\hline $\begin{array}{l}\text { Cluster 6: Social Media } \\
\text { CB }\end{array}$ & $\begin{array}{l}\text { - They emerge as fundamental to maintain the feeling of proximity to } \\
\text { peers and security in access to knowledge. } \\
\text { - They have promoted increased information overload and cybercrime, } \\
\text { registering an evolution of the perceived severity of the situation and } \\
\text { cybercrime. } \\
\text { - Online shopping for essential products increased during the adjustment } \\
\text { phase. } \\
\text { - Touching the interface of the technological device is important to infer } \\
\text { information about the products. }\end{array}$ \\
\hline
\end{tabular}




\section{CONCLUSIONS}

This study aimed to map the scientific publications, intellectual structure, and research trends in CB in the COVID-19 pandemic. Thus, on the one hand, it aimed to identify the key contributions of research in this area of knowledge and, on the other hand, to determine the lines of research that constitute the most prominent intellectual structure in this area of knowledge. We now intend to answer the research question on which this study was based:

$R Q$ 1: What are the main topics developed in CB literature on COVID-19?

Thus, and in response to our first research question, the literature review identified six key thematic areas in the research on CB during the pandemic: Environmental Factors, Social Media CB and Business Strategies, Personal and Psychological Characteristics, Purchase Process and Panic buying.

This study has direct implications for the literature on CB in disruptive moments, such as the current pandemic, especially by identifying the issues that have been investigated, their contributions, and main findings. It thus provides the literature mapping that allows the scientific community to know the main issues debated, the findings, and the uncertainties.

The brain plasticity that guides the human being will once again be present in this postpandemic period, adapting needs, desires, and purchasing processes, where the stimuli provided by real people, the projection of social comfort, the attentional capacity of brands, involvement in collective purposes, or even the digitalization of the simplest or most complex daily path will be drivers of the $\mathrm{CB}$. Companies must therefore preserve the engaging, fast, and continuous purchase journey in all channels, surprising with authenticity, new and immersive experiences, allowing beliefs to change and be consolidated, making consumers more willing to repeat the behavior.

\section{1 Research agenda}

Finally, our contribution to identifying main research gaps in $\mathrm{CB}$ literature and how could future avenues of research be shape is presented in Table 7. The lines of research are displayed by thematic area. 
Table 7. Future lines of research

\begin{tabular}{|c|c|}
\hline $\begin{array}{l}\text { Prevailing } \\
\text { Approaches }\end{array}$ & Future lines of research \\
\hline $\begin{array}{l}\text { Cluster 1: Personal } \\
\text { and psychological } \\
\text { characteristics }\end{array}$ & $\begin{array}{l}\text { - Study how generations, gender, employment status, family size, } \\
\text { income, place of residence, mobility patterns, shopping habits, and } \\
\text { lifestyles influence CB in times of crisis. } \\
\text { - Segment the purchasing behaviors of Generations } \mathrm{Z} \text { and Alpha in } \\
\text { the face of social changes promoted by the pandemic. }\end{array}$ \\
\hline $\begin{array}{l}\text { Cluster 2: Macro- } \\
\text { Environmental } \\
\text { factors }\end{array}$ & $\begin{array}{l}- \text { Cluster consumer surroundings enhancement policies } \\
\text { - Identify the emergence of brands oriented toward gender and } \\
\text { sexual orientation diversity during the COVID-19 pandemic. }\end{array}$ \\
\hline $\begin{array}{l}\text { Cluster 3: Business } \\
\text { and marketing } \\
\text { strategies }\end{array}$ & $\begin{array}{l}\text { - Identify the ability to apply strategies that articulate tangible and } \\
\text { measurable benefits from investments. } \\
\text { - Evaluate which marketing strategies have proven most effective }\end{array}$ \\
\hline $\begin{array}{l}\text { Cluster 4: Panic } \\
\text { buying }\end{array}$ & $\begin{array}{l}\text { Know the usage rates of direct and automated communication } \\
\text { media such as chatbot during pandemic moments, linking } \\
\text { responsiveness with the conversation-to-sale rate. } \\
\text { - Cluster the types of promotions conducted by the technology sector } \\
\text { during the COVID-19 pandemic. }\end{array}$ \\
\hline $\begin{array}{l}\text { Cluster 5: Purchase } \\
\text { Process }\end{array}$ & $\begin{array}{l}\text { Identify whether stimuli such as Price or Quality play an impacting } \\
\text { role in the consumer's decision-making process. }\end{array}$ \\
\hline $\begin{array}{l}\text { Cluster 6: Social } \\
\text { mediaCB }\end{array}$ & $\begin{array}{l}\text { - Understanding the capacity of macro-influencers to engage and } \\
\text { reach out in the post-pandemic period. } \\
\text { - Mapping the emergence of the marketplace on social networks } \\
\text { during the COVID-19 pandemic period. }\end{array}$ \\
\hline
\end{tabular}

\subsection{Limitations}

Nevertheless the identified contributions, the study has limitations, particularly the fact that the literature review is not exhaustive since only the WoS database was used to collect the articles that were part of the study. Although the WoS database is an international reference database, the collection of articles in other databases and sources, such as the SCOPUS database, could provide new perspectives of analysis on the CB in these times. The conclusions also present limitations inherent to systematic literature review articles, in particular the filters used to limit the search. Although we have tried to integrate as many published articles as possible, another limitation results from the fact that new articles are being published daily and in high prevalence.

Acknowledgements: This work is financed by national funds through FCT - Fundação para a Ciência e a Tecnologia, I. P., under the project "UIDB/04630/2020". 


\section{REFERENCES}

Abdulmuhsin, A. A., Degirmenci, B., Efendioglu, I. H., \& Durmaz, Y. (2021). The perception of COVID-19 and avoidance behavior in Turkey: the role of income level, gender and education. International Journal of Emerging Markets.

https://doi.org/10.1108/IJOEM-11-2020-1308

Akhtar, N., Akhtar, M. N., Usman, M., Ali, M., \& Siddiqi, U. I. (2020). COVID-19 restrictions and consumers' psychological reactance toward offline shopping freedom restoration. Service industries journal, 40(13-14), 891-913.

https://doi.org/10.1080/02642069.2020.1790535

Alessa, A. A., Alotaibie, T. M., Elmoez, Z., \& Alhamad, H. E. (2021). Impact of COVID19 on Entrepreneurship and Consumer Behaviour: A Case Study in Saudi Arabia. Journal of Asian Finance Economics and Business, 8(5), 201-210.

https://doi.org/10.13106/jafeb.2021.vol8.no5.0201

Alhaimer, R. (2021). Fluctuating Attitudes and Behaviors of Customers toward Online Shopping in Times of Emergency: The Case of Kuwait during the COVID-19 Pandemic. Journal of Internet Commerce. https://doi.org/10.1080/15332861.2021.1882758

Almeida, R. P., Proença, J. F., \& Ferreira, F. N. H. (2021). Value Co-Creation and Sustainability: A systematic literature review. International Journal of Marketing, Communication and New Media, 9(June), 104-125.

Ardanza-Ruiz, P., \& Lavin, J. M. (2021). Supermarkets, social media and covid-19: neuromarketing and humanisation of the message. Vivat Academia, (154), 361-379. https://doi.org/10.15178/va.2021.154.e1356

Ariely, D. (2009). Predictably Irrational: The hidden forces that shape our decisions, [Kindle Edition].

Baarsma, B., \& Groenewegen, J. (2021). COVID-19 and the Demand for Online Grocery Shopping: Empirical Evidence from the Netherlands. Economist-Netherlands. https://doi.org/10.1007/s10645-021-09389-y

Baicu, C. G., Gardan, I. P., Gardan, D. A., \& Epuran, G. (2020). The impact of COVID-19 on consumer behavior in retail banking. Evidence from Romania. Management \& Marketing-Challenges for the Knowledge Society, 15(1), 534-556.

https://doi.org/10.2478/mmcks-2020-0031

Baran, T. (2021). COVID effect on retailing: a study on consumers' retailer preferences during economic recession periods: evidence from Turkey as a predominantly Muslim society. Journal of Islamic Marketing. https://doi.org/10.1108/JIMA-09-2020-0292

Barnes, S. J., Diaz, M., \& Arnaboldi, M. (2021). Understanding panic buying during COVID-19: A text analytics approach. Expert Systems with Applications, 169. https://doi.org/10.1016/j.eswa.2020.114360

Bauman, Z. (2001). Modernidade líquida. Editora Schwarcz-Companhia das Letras.

Billore, S., \& Anisimova, T. (2021). Panic buying research: A systematic literature review and future research agenda. International Journal of Consumer Studies, 45(4), 777-804. https://doi.org/10.1111/ijcs.12669

Braha, D. (2012). Global civil unrest: contagion, self-organization, and prediction. PloS ONE, 7(10), e48596.

Bright, L. F., \& Schau, H. J. (2021). Pop-Up Special Section Introduction: Advertising and COVID-19-Examining the Impacts of the Pandemic on Agencies, Consumers, and Brands. 
Journal of Advertising, 50(3), 217-220. https://doi.org/10.1080/00913367.2021.1933657 Cachero-Martinez, S. (2020). Consumer Behaviour towards Organic Products: The Moderating Role of Environmental Concern. Journal of Risk and Financial Management, 13(12). https://doi.org/10.3390/jrfm13120330

Campbell, M. C., Inman, J. J., Kirmani, A., \& Price, L. L. (2020). In Times of Trouble: A Framework for Understanding Consumers' Responses to Threats. Journal of Consumer Research, 47(3), 311-326. https://doi.org/10.1093/jcr/ucaa036

Chua, G., Yuen, K. F., Wang, X., \& Wong, Y. D. (2021). The Determinants of Panic Buying during COVID-19. International Journal of Environmental Research and Public Health, 18(6), 3247.

Cox, N., Ganong, P., Noel, P., Vavra, J., Wong, A., Farrell, D., ... Deadman, E. (2020). Initial Impacts of the Pandemic on Consumer Behavior: Evidence from Linked Income, Spending, and Savings Data. Brookings Papers On Economic Activity, (SI), 35-69. https://doi.org/10.1353/eca.2020.0006

de la Pena de Leon, A., Saucedo Soto, J. M., Amezcua Nunez, J. B., \& Balleza, I. C. (2020). Living the pandemic with rhythm, knowledge and humor. Caderno Profissional de Marketing UNIMEP, 8(4, SI), 8-18.

de Oliveira, I. K., de Oliveira, L. K., Amorim Faria Lisboa, M. R., Nunes Madalon, E. C., de Freitas, L. F., \& Peres Filho, A. C. (2021). The Geographical Distance between Producers and Consumers of the Organic Street Markets: The Case of Belo Horizonte, Brazil. Logistics-Basel, 5(2). https://doi.org/10.3390/logistics5020030

do Amaral Moretti, S. L., da Silva Gabriel, M. L., do Prado, R. A., \& Alcantara Fagundes, A. F. (2021). Consumer behavior during the COVID-19 pandemic: latent class analysis on coping attitudes and buying habits. Estudios Gerenciales, 37(159), 303-317. https://doi.org/10.18046/j.estger.2021.159.4433

Donthu, N., \& Gustafsson, A. (2020). Effects of COVID-19 on business and research. Journal of Business Research, 117, 284-289. https://doi.org/10.1016/j.jbusres.2020.06.008 Dsouza, D., \& Sharma, D. (2021). Online food delivery portals during COVID-19 times: an analysis of changing consumer behavior and expectations. International Journal of Innovation Science, 13(2), 218-232. https://doi.org/10.1108/IJIS-10-2020-0184

Eger, L., Komarkova, L., Egerova, D., \& Micik, M. (2021). The effect of COVID-19 on consumer shopping behaviour: Generational cohort perspective. Journal of Retailing and Consumer Services, 61. https://doi.org/10.1016/j.jretconser.2021.102542

Ellison, B., McFadden, B., Rickard, B. J., \& Wilson, N. L. W. (2021). Examining Food Purchase Behavior and Food Values During the COVID-19 PandemicJEL codes. Applied Economic Perspectives and Policy, 43(1), 58-72. https://doi.org/10.1002/aepp.13118 Esposito, G., Setoh, P., Shinohara, K., \& Bornstein, M. H. (2017). The development of attachment: Integrating genes, brain, behavior, and environment. Behavioural Brain Research, 325, 87-89.

Finsterwalder, J., Kabadayi, S., Fisk, R. P., \& Boenigk, S. (2021). Creating hospitable service systems for refugees during a pandemic: leveraging resources for service inclusion. Journal of Service Theory and Practice, 31(2, SI), 247-263. https://doi.org/10.1108/JSTP07-2020-0175

Garner, T., Safir, A., \& Schild, J. (2020). Changes in consumer behaviors and financial well-being during the coronavirus pandemic: results from the US Household Pulse Survey. Monthly Labor Review.

Giroux, M., Park, J., Kim, J.-E., Choi, Y. K., Lee, J. C., Kim, S. (Sam), ... Kim, J. (2021). 
The Impact of Communication Information on the Perceived Threat of COVID-19 and Stockpiling Intention. Australasian Marketing Journal. https://doi.org/10.1177/18393349211028670

Goolsbee, A., \& Syverson, C. (2021). Fear, lockdown, and diversion: Comparing drivers of pandemic economic decline 2020. Journal of Public Economics, 193. https://doi.org/10.1016/j.jpubeco.2020.104311

Gordon-Wilson, S. (2021). Consumption practices during the COVID-19 crisis. international Journal of Consumer Studies. https://doi.org/10.1111/ijcs.12701

Gupta, S., Simon, K., \& Wing, C. (2020). Mandated and Voluntary Social Distancing during the COVID-19 Epidemic. Brookings Papers on Economic Activity, (SI), 269-315. https://doi.org/10.1353/eca.2020.0011

Guthrie, C., Fosso-Wamba, S., \& Arnaud, J. B. (2020). Online consumer resilience during a pandemic: An exploratory study of e-commerce behavior before, during and after a COVID-19 lockdown. Journal of Retailing and Consumer Services, 61. https://doi.org/10.1016/j.jretconser.2021.102570

Halan, D. (2020). Antecedents of Online Shopping Behavioural Intention in Asia's Second Largest Economy. Pacific Business Review International, 13(3), 1-20.

Hall, C. M., Fieger, P., Prayag, G., \& Dyason, D. (2021). Panic Buying and Consumption Displacement during COVID-19: Evidence from New Zealand. Economies, 9(2). https://doi.org/10.3390/economies9020046

Hastings, G. (2007). Social marketing: Why should the devil have all the best tunes? Elsevier.

Hawkins, D. T. (1977). Unconventional Uses of On-line Information Retrieval Systems : On-line Bibliometric Studies. Journal of the American Society for Information Science, 28(1), 13-18.

Hofmann, V., Stokburger-Sauer, N. E., Wanisch, A., \& Hebborn, H. (2021). Masked smiles matter - employee verbal expertise and emotion display during COVID-19. Service Industries Journal, 41(1-2, SI), 107-137. https://doi.org/10.1080/02642069.2021.1873296 Huang, H., \& Liu, S. Q. (2020). Donate to help combat COVID-19! How typeface affects the effectiveness of CSR marketing? International Journal of Contemporary Hospitality Management, 32(10), 3315-3333. https://doi.org/10.1108/IJCHM-05-2020-0462

Im, J., Kim, J., \& Choeh, J. Y. (2021). COVID-19, social distancing, and risk-averse actions of hospitality and tourism consumers: A case of South Korea. Journal of Destination Marketing \& Management, 20. https://doi.org/10.1016/j.jdmm.2021.100566

Iriani, S. S., Nuswantara, D. A., Kartika, A. D., \& Purwohandoko, P. (2021). The Impact of Government Regulations on Consumers Behaviour during the COVID-19 Pandemic: A Case Study in Indonesia. Journal of Asian Finance Economics and Business, 8(4), 939948. https://doi.org/10.13106/jafeb.2021.vol8.no4.0939

Itani, O. S., \& Hollebeek, L. D. (2021). Light at the end of the tunnel: Visitors' virtual reality (versus in-person) attraction site tour-related behavioral intentions during and postCOVID-19. Tourism Management, 84. https://doi.org/10.1016/j.tourman.2021.104290

Kahneman, D. (2011). Thinking, fast and slow. Macmillan.

Kotler, P., Keller, K. L., \& Chernev, A. (2022). Marketing Management (16th ed.). Pearson Education Inc.

Kaur, A., \& Malik, G. (2021). Understanding the Psychology Behind Panic Buying: A Grounded Theory Approach. Global Business Review.

https://doi.org/10.1177/0972150920973504 
Kazancoglu, I., \& Demir, B. (2021). Analysing flow experience on repurchase intention in e-retailing during COVID-19. International Journal of Retail \& Distribution Management. https://doi.org/10.1108/IJRDM-10-2020-0429

Kim, J., Yang, K., Min, J., \& White, B. (2021). Hope, fear, and consumer behavioral change amid COVID-19: Application of protection motivation theory. International Journal of Consumer Studies. https://doi.org/10.1111/ijcs.12700

Kirk, C. P., \& Rifkin, L. S. (2020). I'll trade you diamonds for toilet paper: Consumer reacting, coping and adapting behaviors in the COVID-19 pandemic. Journal of Business Research, 117, 124-131. https://doi.org/10.1016/j.jbusres.2020.05.028

Krzyk, T., \& Kunst, R. (2012). Redes Sociais na Internet: contextualização, mercado e desenvolvimento. Cippus, 1(2), 74-97.

Laato, S., Islam, A. K. M. N., Farooq, A., \& Dhir, A. (2020). Unusual purchasing behavior during the early stages of the COVID-19 pandemic: The stimulus-organism-response approach. Journal of Retailing and Consumer Services, 57.

https://doi.org/10.1016/j.jretconser.2020.102224

Lavuri, R. (2021). Intrinsic factors affecting online impulsive shopping during the COVID-19 in emerging markets. International Journal of Emerging Markets. https://doi.org/10.1108/IJOEM-12-2020-1530

Li, J., Hallsworth, A. G., \& Coca-Stefaniak, J. A. (2020). Changing Grocery Shopping Behaviours Among Chinese Consumers At The Outset of The COVID-19 Outbreak. Tijdschrift Voor Economische en Sociale Geografie, 111(3, SI), 574-583.

https://doi.org/10.1111/tesg.12420

Lim, W. M. (2021). Toward an agency and reactance theory of crowding: Insights from COVID-19 and the tourism industry. Journal of Consumer Behaviour.

https://doi.org/10.1002/cb.1948

Liu, C., Xia, S., \& Lang, C. (2021). Clothing Consumption During the COVID-19 Pandemic: Evidence From Mining Tweets. Clothing and Textiles Research Journal. https://doi.org/10.1177/0887302X211014973

Loxton, M., Truskett, R., Scarf, B., Sindone, L., Baldry, G., \& Zhao, Y. (2020). Consumer Behaviour during Crises: Preliminary Research on How Coronavirus Has Manifested Consumer Panic Buying, Herd Mentality, Changing Discretionary Spending and the Role of the Media in Influencing Behaviour. Journal of Risk and Financial Management, 13(8). https://doi.org/10.3390/jrfm13080166

Maltese, I., Le Pira, M., Marcucci, E., Gatta, V., \& Evangelinos, C. (2021). Grocery or @ grocery: A stated preference investigation in Rome and Milan. Research In Transportation Economics, 87. https://doi.org/10.1016/j.retrec.2021.101096

Mason, A. N., Brown, M., Mason, K., \& Narcum, J. (2021). Pandemic effects on social media marketing behaviors in India. COGENT BUSINESS $\backslash \&$ MANAGEMENT, 8(1). https://doi.org/10.1080/23311975.2021.1943243

Mason, A. N., Narcum, J., \& Mason, K. (2021). Social media marketing gains importance after COVID-19. Cogent Business \& Management, 8(1).

https://doi.org/10.1080/23311975.2020.1870797

Maulana, N. (2020). Research Trends in Marketing Science Before COVID-19 Outbreak: A Literature Review. Management \& Marketing-Challenges for the Knowledge Society, 15(1), 514-533. https://doi.org/10.2478/mmcks-2020-0030

McCann, S. (2009). Social proof: a tool for determining authority. The Library with the Lead Pipe. 
McGue, M., \& Bouchard Jr, T. J. (1998). Genetic and environmental influences on human behavioral differences. Annual Review of Neuroscience, 21(1), 1-24.

Mecit, A., Shrum, L. J., \& Lowrey, T. M. (2021). COVID-19 is Feminine: Grammatical Gender Influences Danger Perceptions and Precautionary Behavioral Intentions by Activating Gender Stereotypes. Journal of Consumer Psychology.

https://doi.org/10.1002/jcpy.1257

Mendez-Wong, A., Ana Aguilar-Garces, E., Alicia Villarreal-Cavazos, J., \& Alcantara Hernandez, R. J. (2020). Consumer behavior and commercial response in times of COVID-19. Caderno Profissional De Marketing UNIMEP, 8(4, SI), 165-180.

Milakovic, I. K. (2021). Purchase experience during the COVID-19 pandemic and social cognitive theory: The relevance of consumer vulnerability, resilience, and adaptability for purchase satisfaction and repurchase. International Journal of Consumer Studies. https://doi.org/10.1111/ijcs.12672

Min, J., Yang, K., \& Kim, J. (2021). The role of perceived vulnerability in restaurant customers' co-creation behavior and repatronage intention during the COVID-19 pandemic. Journal of Vacation Marketing. https://doi.org/10.1177/13567667211014932 Müller-Oehring, E. M., \& Schulte, T. (2014). Cognition, emotion, and attention. Handbook of Clinical Neurology, 125, 341-354.

Musyaffi, A. M., Sari, D. A. P., \& Respati, D. K. (2021). Understanding of Digital Payment Usage During COVID-19 Pandemic: A Study of UTAUT Extension Model in Indonesia. Journal of Asian Finance Economics and Business, 8(6), 475-482. https://doi.org/10.13106/jafeb.2021.vol8.no6.0475

Mutschke, P., Mayr, P., Schaer, P., \& Sure, Y. (2011). Science models as value-added services for scholarly information systems. Scientometrics, 89(1), 349-364. https://doi.org/10.1007/s11192-011-0430-x

Nakano, Y. (2012). A grande recessão: oportunidade para o Brasil alcançar os países desenvolvidos. Revista de Administração de Empresas, 52, 264-270.

Nayal, P., Pandey, N., \& Paul, J. (2021). COVID-19 pandemic and consumer-employeeorganization wellbeing: A dynamic capability theory approach. Journal of Consumer Affairs. https://doi.org/10.1111/joca.12399

Nielsen. (2020). Key Consumer Behavior Thresholds Identified as the Coronavirus Outbreak Evolves.

Nofiani, D., Indarti, N., Lukito-Budi, A. S., \& Manik, H. F. G. G. (2021). The dynamics between balanced and combined ambidextrous strategies: a paradoxical affair about the effect of entrepreneurial orientation on SMEs' performance. Journal of Entrepreneurship In Emerging Economies. https://doi.org/10.1108/JEEE-09-2020-0331

Norris, J. I., de Calvo, M. P., \& Mather, R. D. (2020). Managing an existential threat: how a global crisis contaminates organizational decision-making. Management Decision, 58(10, SI), 2117-2138. https://doi.org/10.1108/MD-08-2020-1034

Oana, D. (2020). The impact of the current crisis generated by the COVID-19 pandemic on consumer behavior. Studies In Business and Economics, 15(2), 85-99.

https://doi.org/10.2478/sbe-2020-0027

Ohme, R., Reykowska, D., Wiener, D., \& Choromanska, A. (2010). Application of frontal EEG asymmetry to advertising research. Journal of Economic Psychology, 31(5), 785-793. Ortega-Vivanco, M. (2020). Effects of COVID-19 on consumer behavior: Ecuador case. RETOS-Revista de Ciencias de la Administracion y Economia, 10(20), 233-247. https://doi.org/10.17163/ret.n20.2020.03 
Osareh, F. (1996). Bibliometrics, Citation Analysis and Co-Citation Analysis: A Review of Literature I. Libri, 46(3), 149-158.

Pan, T., Shu, F., Kitterlin-Lynch, M., \& Beckman, E. (2021). Perceptions of cruise travel during the COVID-19 pandemic: Market recovery strategies for cruise businesses in North America. Tourism Management, 85. https://doi.org/10.1016/j.tourman.2020.104275

Pantano, E., Pizzi, G., Scarpi, D., \& Dennis, C. (2020). Competing during a pandemic? Retailers' ups and downs during the COVID-19 outbreak. Journal of Business Research, 116, 209-213. https://doi.org/10.1016/j.jbusres.2020.05.036

Pantano, E., Priporas, C.-V., Devereux, L., \& Pizzi, G. (2021). Tweets to escape: Intercultural differences in consumer expectations and risk behavior during the COVID-19 lockdown in three European countries. Journal of Business Research, 130, 59-69. https://doi.org/10.1016/j.jbusres.2021.03.015

Paul, J., Menzies, J., Zutshi, A., \& Cai, H. (2020). New and novel business paradigms in and from China and India. European Business Review, 32(5, SI), 785-800. https://doi.org/10.1108/EBR-09-2020-0224

Pham, V. K., Do Thi, T. H., \& Ha Le, T. H. (2020). A study on the COVID-19 awareness affecting the consumer perceived benefits of online shopping in Vietnam. Cogent Business \& Management, 7(1). https://doi.org/10.1080/23311975.2020.1846882

Prentice, C., Chen, J., \& Stantic, B. (2020). Timed intervention in COVID-19 and panic buying. Journal of Retailing and Consumer Services, 57.

https://doi.org/10.1016/j.jretconser.2020.102203

Prentice, C., Nguyen, M., Nandy, P., Winardi, M. A., Chen, Y., Le Monkhouse, L., ... Stantic, B. (2021). Relevant, or irrelevant, external factors in panic buying. Journal of Retailing and Consumer Services, 61. https://doi.org/10.1016/j.jretconser.2021.102587

Prentice, C., Quach, S., \& Thaichon, P. (2021). Antecedents and consequences of panic buying: The case of COVID-19. International journal of consumer studies. https://doi.org/10.1111/ijcs.12649

Racat, M., Capelli, S., \& Lichy, J. (2021). New insights into 'technologies of touch': Information processing in product evaluation and purchase intention. Technological Forecasting and Social Change, 170. https://doi.org/10.1016/j.techfore.2021.120900

Radtke, M. L., Brock, A. L., Ostermann, C. M., \& De Almeida, S. O. (2021). Effects of covid-19 on consumer disposal behavior and future business scenarios. Revista Gestao Organizacional, 14(1, SI), 294-315. https://doi.org/10.22277/rgo.v14i1.5750

Rejeb, A., Rejeb, K., \& Keogh, J. G. (2020). COVID-19 and the food chain? impacts and future research trends. Logforum, 16(4), 475-485.

https://doi.org/10.17270/J.LOG.2020.502

Rybaczewska, M., Sulkowski, L., \& Bilan, Y. (2021). COVID-19 Pandemic and Independent Convenience Stores in the United Kingdom. Inzinerine EkonomikaEngineering Economics, 32(3), 258-265. https://doi.org/10.5755/j01.ee.32.3.28360

Safara, F. (2021). A Computational Model to Predict Consumer Behaviour During COVID-19 Pandemic. Computational Economics. https://doi.org/10.1007/s10614-02010069-3

Sanchez-Valdes, A., \& Nava-Rogel, R. M. (2020). Perspective of restaurant SMEs in the current scenario of the covid-19 crisis. 3C Empresa, (SI), 129-147.

https://doi.org/10.17993/3cemp.2020.edicionespecial1.129-147

Sapolsky, R. M. (2017). Behave: The biology of humans at our best and worst. Penguin.

Schiffman, L., \& Wisenblit, J. L. (2019). Consumer Behavior (12th ed.). Pearson. 
Sharma, M. K. (2014). The impact on consumer buying behaviour: Cognitive dissonance. Global Journal of Finance and Management, 6(9), 833-840.

Sheth, J. (2020). Impact of COVID-19 on consumer behavior: Will the old habits return or die? Journal of Business Research, 117, 280-283.

https://doi.org/10.1016/j.jbusres.2020.05.059

Silva, E. S., \& Bonetti, F. (2021). Digital humans in fashion: Will consumers interact? Journal of Retailing and Consumer Services, 60.

https://doi.org/10.1016/j.jretconser.2020.102430

Silva, L. E. N., Neto, M. B. G., Grangeiro, R. da R., \& de Nadae, J. (2021). COVID-19 pandemic: why does it matter for consumer research? Revista Brasileira de Marketing, 20(2), 252-278. https://doi.org/10.5585/remark.v20i2.18677

Solomon, M. R., White, K., Dahl, D. W., Zaichkowsky, J. L., \& Polegato, R. (2017). Consumer behavior: Buying, having, and being. Pearson Boston, MA.

Staddon, J. E. R., \& Cerutti, D. T. (2003). Operant conditioning. Annual Review of Psychology, 54(1), 115-144.

Sunarjo, W. A., Nurhayati, S., \& Muhardono, A. (2021). Consumer Behavior Toward Adoption of Mobile Payment: A Case Study in Indonesia During the COVID-19 Pandemic. Journal of Asian Finance Economics and Business, 8(4), 581-590.

https://doi.org/10.13106/jafeb.2021.vol8.no4.0581

Szymkowiak, A., Gaczek, P., Jeganathan, K., \& Kulawik, P. (2021). The impact of emotions on shopping behavior during epidemic. What a business can do to protect customers. Journal of Consumer Behaviour, 20(1). https://doi.org/10.1002/cb.1853

Tan, K.-L., Sia, J. K.-M., \& Tang, D. K. H. (2021). To verify or not to verify: using partial least squares to predict effect of online news on panic buying during pandemic. Asia Pacific Journal of Marketing and Logistics. https://doi.org/10.1108/APJML-02-2021-0125 Terres, M. da S., Rohden, S. F., Vedolin, L., Hein Machado, B. F., Magnus, K., Altmann, A., \& Bernieri Schiavon, D. E. (2020). The COVID-19 Pandemic: paths for future research in marketing involving the regulatory role of prosocial consumption. Revista Brasileira de Marketing, 19(3), 611-641. https://doi.org/10.5585/remark.v19i3.17103

Thomsom Reuters. (2008). Using bibliometrics: A guide to evaluating research performance with citation data (Retrieved).

http://ip-science.thomsonreuters.com/m/pdfs/325133_thomson.pdf

Tiago, A., \& Veiga, P.M. (2021). Comércio tradicional: O novo paradigma de comportamento do consumidor resultante da COVID-19. Portuguese Journal of Finance, Management and Accounting, 7(14), 85 - 105.

Toubes, D. R., Araujo Vila, N., \& Fraiz Brea, J. A. (2021). Changes in Consumption Patterns and Tourist Promotion after the COVID-19 Pandemic. Journal of Theoretical and Applied Electronic Commerce Research, 16(5), 1332-1352.

https://doi.org/10.3390/jtaer16050075

van Eck, N. J., \& Waltman, L. (2009). VOSviewer : A Computer Program for Bibliometric Mapping. ERIM Report Series Research In Management.

van Eck, N. J., \& Waltman, L. (2010). Software survey: VOSviewer, a computer program for bibliometric mapping. Scientometrics, 84(2), 523-538. https://doi.org/10.1007/s11192009-0146-3

Verhoef, P. C. (2021). Omni-channel retailing: some reflections. Journal of Strategic Marketing, 29(7, SI), 608-617. https://doi.org/10.1080/0965254X.2021.1892163

Veselovska, L., Zavadsky, J., \& Bartkova, L. (2021). Consumer behaviour changes during 
times of the covid-19 pandemic: an empirical study on Slovak consumers. $E \& M$ Ekonomie a Management, 24(2), 136-152. https://doi.org/10.15240/tul/001/2021-2-009

Virmani, K., \& Kaur, M. (2020). COVID-19: A journey of Indian consumers from normal to new normal. The Journal of Indian Management \& Strategy, 25(4), 48-52. https://doi.org/10.5958/0973-9343.2020.00032.0

Vrontis, D., \& Basile, G. (2021). New media marketing as a driver of enterprise country of origin (COO) offer in international markets. International Journal of Entrepreneurial Behavior \& Research. https://doi.org/10.1108/IJEBR-01-2021-0085

Yang, K., Kim, J., Min, J., \& Hernandez-Calderon, A. (2021). Effects of retailers' service quality and legitimacy on behavioral intention: the role of emotions during COVID-19. Service Industries Journal, 41(1-2, SI), 84-106.

https://doi.org/10.1080/02642069.2020.1863373

Yuen, K. F., Wang, X., Ma, F., \& Li, K. X. (2020). The psychological causes of panic buying following a health crisis. International Journal of Environmental Research and Public Health, 17(10), 3513.

Zhang, X., Liu, H., \& Yao, P. (2021). Research Jungle on Online Consumer Behaviour in the Context of Web 2.0: Traceability, Frontiers and Perspectives in the Post-Pandemic Era. Journal of Theoretical and Applied Electronic Commerce Research, 16(5), 1740-1767. https://doi.org/10.3390/jtaer16050098

Zulauf, K., \& Wagner, R. (2021). Online Shopping Therapy: If You Want to Be Happy, Shop around. Journal of International Consumer Marketing.

https://doi.org/10.1080/08961530.2021.1955425

Zwanka, R. J., \& Buff, C. (2021). COVID-19 Generation: A Conceptual Framework of the Consumer Behavioral Shifts to Be Caused by the COVID-19 Pandemic. Journal of International Consumer Marketing, 33(1), 58-67.

https://doi.org/10.1080/08961530.2020.1771646

\section{How to cite this article:}

Veiga, P. M. \& e Diogo, J. (2022). Consumer Behavior: A Literature Review of the Early Research on the COVID-19 Outbreak, International Journal of Marketing, Communication and New Media. Special Issue on Marketing in the Context of COVID-19, January 2022, 62-91. 